\title{
Steroid kullanan supratentoryal kitle olgularında intravenöz granisetron ve ondansetron uygulamalarının postoperatif bulantı, kusma üzerine olan etkilerinin karşılaştırılması
}

\author{
Oylum Selçuk', İnci Paksoy², Hacer Șebnem Türk², Faruk Seçkin Yücesoy², Enis Selçuk', Güneri Atalan², Sibel Oba²
}

ÖZET:

Steroid kullanan supratentoryal kitle olgularında intravenöz granisetron ve ondansetron uygulamaIarının postoperatif bulantı, kusma üzerine olan etkilerinin karşılaştırılması

Giriş ve Amaç: Postoperatif bulantı kusma (POBK) hastanede kalış süresini, hastalığın düzelmesini ve derlenme zamanını uzatır. Ayrıca, kraniyotomi sonrası kafa içi basınç artışına sebep olarak kanama riskini arttırmaktadır.

Çalışmamızda intrakranial girișim yapılacak steroid tedavisi altındaki hastalarda steroidin tek başına veya granisetron ve ondansetron ile kombine kullanımının POBK üzerine etkinliğini karșılaștırmayı amaçladık.

Gereç ve Yöntem: Nöroşirurji Kliniğinde supratentoryal kitle nedeniyle opere olaçak olgular üzerinde yapıldı. ASA I-II, 18-70 Gereç ve Yöntem: Nöroşirurji Kliniğinde supratentoryal kitle nedeniyle opere olacak olgular üzerinde yapıldı. ASA I-II, 18-70
yaş arası 90 olgu çalışmaya dahil edildi. Çalışmamız prospektif, randomize ve çift kör olarak planlandı. Postoperatif 24 saatlik sürede her 6 saatte tüm olgulara intravenöz olarak $4 \mathrm{mg}$ deksametazon uygulandı. Tüm olgulara, genel anestezi uygulandı. Ameliyat bitiminde, duramater kapatılırken,3 gruba ayrılan olgularda; Grup 1'e serum fizyolojik, Grup 2'ye 8 mg ondansetron, Grup 3'e mg granisetron uygulandı.Operasyon ve anestezi süreleri, postoperatif $0,2,4,6,8,10,12,16$, 24. saatlerde bulantı için Verbal Destriktif Skala değerleri, kusma varlığı, antiemetik tüketimi, yan etkiler kaydedildi.

Bulgular: Grup 1, Grup 2 ve Grup 3 ün 0.-10.Saatler arası bulantı şiddeti dağılımları arasında istatistiksel olarak anlamlı farkııık gözlenmiştir ( $p=0,0001)$. Grup 1 de bulantı varlığı Grup 2 ve grup 3 den istatistiksel olarak anlamlı derecede yüksek bulunmuštur. Grup 1, Grup 2 ve Grup 3 ün 12-24.Saatler arası bulantı șiddeti dağıımları arasında istatistiksel olarak anlamlı farklıık gözlenmemiştir. Kontrol grubunda ilk 6 saatteki, ondansetron grubunda ilk 4 saatteki, granisetron grubunda 1. saatteki bulant varlığı diğer zamanlara göre istatiksel olarak anlamlı derecede yüksek bulunmuştur. Grup 1, Grup 2 ve Grup 3 ün 0.-10. Saatler arası kusma varlığı dağılımları arasında istatistiksel olarak anlamlı farklılık gözlenmiştir $(p=0,0001)$. Grup 1 de kusma varlığı Grup 2 ve grup 3 den istatistiksel olarak anlamlı derecede yüksek bulunmuştur.Grup 1, Grup 2 ve Grup 3 ün 12.-24. Saatler arası kusma varlığı dağııımları arasında istatistiksel olarak anlamlı farkıılık gözlenmemiștir. Kontrol grubunda ilk 4 saatteki, ondansetron grubunda ilk 2 saatteki kusma varlığı diğer saatlere göre istatistiksel olarak anlamlı derecede yüksekti. Granisetron grubunda hiç kusma görülmedi.

Grup 1, Grup 2 ve Grup 3' ün antiemetik intiyacı varlığı dağılımları arasında istatistiksel olarak anlamlı farklıık gözlenmiștir $(p=0,02)$. Grup 1 de antiemetik intiyacı varlığı Grup 2 ve grup 3 den istatistiksel olarak anlamlı derecede yüksek bulunmuştur. Grupların hiçbirinde yan etki ile karşılaşımamıştır.

Sonuç: Supratentorial kitle nedeniyle opere olan olgularda deksametazonun tek başına antiemetik etkinliğinin yeterli olmadığı, ondansetron ve granisetron ile kombine kullanıldı̆ıında POBK'un önlenmesinde etkili olduğunu tespit ettik. Granisetron alan hasta grubunda daha az bulantı-kusma görülmesine rağmen ondansetron ve granisetron POBK açısından benzer etkinlik göstermiştir. Anahtar kelimeler: Postoperatif bulantı ve kusma, granisetron, ondansetron

ABSTRACT:

Comparison of the effects of granisetron and ondansetron on postoperative nausea and vomiting in supratentorial tumor patients using steroids

objective: Postoperative nausea and vomiting (PONV) delays patient discharge and increases recovery room stays and recovery time. Furthermore, it increases the bleeding risk by causing increased intracranial pressure after craniotomy. The aim of this study was to compare the efficacy of steroids or steroids combined with ondansetron and granisetron in patients undergoing intracranial surgery.

Methods: The study was conducted on the patients undergoing supratentorial tumor surgery in the neurosurgery unit. 90 patients, classified as ASA physical status I and II, aged between 17-70 were included in this study. The study was planned as a prospective, randomized, double-blinded study. All the patients were medicated with $4 \mathrm{mg}$ dexamethasone intravenously a prospective, randomized, double-blinded study. All the patients were medicated with $4 \mathrm{mg}$ dexamethasone intravenously the surgery, and the patients were divided into 3 groups. Group 1 was treated with saline, Group 2 was treated with $8 \mathrm{mg}$ ondansetron, and Group 3 was treated with $8 \mathrm{mg}$ granisetron. Durations of operation and anesthesia, verbal destructive scale values for nausea at the postoperative $0^{\text {th }}, 2^{\text {nd }}, 4^{\text {th }}, 6^{\text {th }}, 8^{\text {th }}, 12^{\text {th }}, 16^{\text {th }}, 24^{\text {th }}$ hours, existence of vomiting, use of antiemetics, and side effects were collected.

Results: The nausea score distributions of Group 1, Group 2 and Group 3 between Oth to $10^{\text {th }}$ hour were significantly different $(p=0.0001)$. Nausea scores in Group 1 were significantly higher than Groups 2 and 3, whereas the difference between Group 1 , Group 2 and Group 3 was found statistically insignificant between $12^{\text {th }}$ to $24^{\text {th }}$ hours. The nausea score distributions of the control group for the first 6 hours, ondansetron group for the first 4 hours and granisetron group for the first hour were significantly higher when compared to the other times.

The existence of vomiting in Group 1, Group 2 and Group 3 was significantly different between $0^{\text {th }}$ to $10^{\text {th }}$ hour $(p=0.0001)$. The existence of vomiting in Group 1 was significantly higher than Group 2 and Group 3. But there was no significant difference between the groups in terms of existence of vomiting between $12^{\text {th }}$ to $24^{\text {th }}$ hours. The existence of vomiting in control group for the first 4 hours and in the ondansetron group for the first 2 hours were significantly higher than the other times, whereas no vomiting was observed in granisetron group.

The distribution of the need for antiemetic use between Group 1, Group 2 and Group 3 was found to be significantly different $(p=0.02)$. The need for antiemetic use in Group 1 was significantly higher from that of Groups 2 and 3. No side effects were observed in any group.

Discussion: The results of our study showed that the antiemetic efficacy of dexamethasone alone was not enough for patients underwent supratentorial tumor surgery but it was effective for prevention of PONV when combined with ondansetron and granisetron. Although less nausea and vomiting has been observed in patients medicated with granisetron, the efficacy of ondansetron and granisetron was similar for preventing PONV.

Key words: Postoperative nausea and vomiting, granisetron, ondansetron

Ş.E.E.A.H. Tıp Bülteni 2013;47(3):109-116
'Sinop Devlet Hastanesi, Anesteziyoloji ve Reanimasyon, Sinop-Türkiye ${ }^{2}$ Şişli Etfal Eğitim ve Araştırma Hastanesi, Anesteziyoloji ve Reanimasyon Kliniği, İstanbul-Türkiye

Yazışma Adresi / Address reprint requests to: Hacer Şebnem Türk, Şişli Etfal Eğitim ve Araştırma Hastanesi, 1. Anesteziyoloji ve Reanimasyon Kliniği, İstanbul-Türkiye

Telefon / Phone: +90-231-2209/5414

E-posta / E-mail:

hacersebnem@yahoo.com.tr

Geliş tarihi / Date of receipt: 20 Mart 2013 / March 20, 2013

Kabul tarihi / Date of acceptance: 5 Eylül 2013 / September 5, 2013 


\section{GíRiş}

Hastalarda anestetik yöntemlere ve ilaçlara bağlı olarak postoperatif dönemde gelişen bulantı-kusma en sık ortaya çıkan yan etkilerdendir. Postoperatif bulantı kusma (POBK) hastanede kalış süresini, hastalığın düzelmesini ve derlenme zamanını uzatır. Bulantı rahatsız edici bir his olup kusma ile birlikte veya tek başına olabilir. Ameliyat sonrası anestetik ve analjezik ilaçların rezidüel etkilerine bağlı olarak hava yolu refleksleri tam olarak dönmediği için postoperatif kusma pulmoner aspirasyon riskini arttırır. İnatçı kusmalar dehidratasyon ve elektrolit imbalansı oluşturabilir (1).

Elektif kraniyotomi sonrası rapor edilen POBK insidansının farklı çalışmalarda \%44'te \%70'e değiştiği belirlenmiştir. Bulantı, özellikle de kusma kraniyotomi sonrası kafa içi basınç artışına sebep olmaktadır $(2,3)$.

Deksametazon düşük dozlarda tek başına veya diğer antiemetiklerle kombine edilerek kullanılır. Oldukça etkili ve ucuz bir antiemetiktir. Ancak, artmış enfeksiyon riski, glukoz intoleransı, gecikmiş yara iyileşmesi, yüzeyel gastrik mukoza ülserasyonu gibi ciddi yan etkilerin mevcut olması POBK için yeni antiemetik arayışlarını gündeme getirmiştir (4).

Ondansetron ve granisetron selektif 5-HT3 reseptör antagonistleridir. Özellikle kemoterapi sonrası görülen bulantı-kusmanın tedavisinde kullanılırlar. Ondansetron son zamanlarda POBK profilaksisi için kullanılmaya başlanmıştır. Tolerasyonları oldukça iyi ve yan etki görülme oranları düşüktür. Ancak tedavi maliyeti yüksektir (5).

Biz de çalışmamızda intrakranial girişim yapılacak steroid tedavisi altındaki hastalarda steroidin tek başına veya granisetron ve ondansetron ile kombine kullanımının postoperatif bulantı kusma üzerine etkinliğini karşılaştırmayı amaçladık.

\section{GíRIŞ VE YÖNTEM}

Bu çalışma Etik Kurul onayı alındıktan sonra Şişli Etfal Eğitim ve Araştırma Hastanesi Nöroşirurji Kliniginde supratentoryal kitle nedeniyle opere olacak olgular üzerinde yapıldı. ASA 1-2 grubundan 18-70 yaş arası preoperatif 24 saat içerisinde steroid alan 90 olgu çalışmaya dahil edildi. Çalışmamız prospektif, randomize ve çift kör olarak planlandı.

İlaçlardan birine aşırı duyarlılığı, kontrolsüz hipertansiyonu ve diabeti, dekompanse kalp yetmezliği, kronik böbrek yetmezliği, peptik ülseri, aktif enfeksiyon hastalığı, nöropsikiyatrik hastalığı, nöromuskuler veya hepatik hastalığı, alkol ve madde bağımlılığı, kronik analjezik (nsaid ve opioid) kullanımı, mental retardasyonu, preoperatif periyotta kusması veya antiemetik ilaç terapisi, POBK öyküsü ve morbid obezitesi olanlar çalışmanın dışında tutuldular.

Tüm olgular, ameliyattan 8 saat önce aç bırakıldılar. Olgulara premedikasyon verilmedi. Postoperatif 24 saatlik sürede her 6 saatte tüm olgulara intravenöz (i.v.) olarak 4 mg deksametazon uygulandı.

Preanestezik visit esnesında olgular çalışma protokolu hakkında bilgilendirildi ve onamları alındı.

Olguların demografik verileri kaydedildi. Ameliyathaneye alınan olgulara D II derivasyonda EKG, noninvaziv tansiyon arteryal, SPO2, ETCO2 monitorizasyonu uygulandı. Periferik ven kanulasyonu 20 G kanülle yapıldı, dengeli elektrolit solüsyonu $10-15 \mathrm{ml} / \mathrm{kg} / \mathrm{h}$ den verildi. Dominant olmayan koldan lokal anestezi altında radiyal artere $20 \mathrm{G}$ kanül yerleştirilerek invaziv arteryel kan basıncı monitorizasyonu yapıldı. \%100 O2 preoksijenasyon uygulandıktan sonra, $1 \mathrm{mcg} / \mathrm{kg}$ fentanyl, $5 \mathrm{mg} / \mathrm{kg}$ tiyopental ve $0,5 \mathrm{mg} / \mathrm{kg}$ atrakuryum ile anestezi indüksiyonu sağlandı. Orotrekeal entübe edilerek idamesi \%50 O2 \%50 hava ve \%4-5 desfluran, $0.5 \mathrm{mg} / \mathrm{kg} /$ saat atrakuryum infüzyonu, $2 \mathrm{mcg} / \mathrm{kg}$ fentanyl ile devam ettirildi. Orotrakeal entübasyondan sonra orogastrik tüp ile midedeki hava ve diğer içerik boşaltıldı. Ekstübasyondan önce orogastrik tüp aspire edilerek çekildi. Olgular, kapalı zarf usulu ile üç gruba ayrıldılar;

Grup $1(n=30)$ : serum fizyolojik

Grup $2(n=30): 8 \mathrm{mg}$ ondansetron (Zofer $8 \mathrm{mg} / 4$ $\mathrm{ml}$ amp-Adeka)

Grup 3 ( $n=30): 3$ mg granisetron (Kytril 3 mg/3ml amp Roche) dura kapatılırken olgulara intravenöz olarak uygulandı.

Antiemetik çalışma dışı bir anestezist tarafından, uyguladığı ajanın hangi grupta olduğu bilmeden uygulandı.

Ameliyat bitiminde, inhalasyon anestezikleri ve 
infüzyonlar sonlandırıldı. Spontan solunumun başlangıcından sonra $0,01 \mathrm{mg} / \mathrm{kg}$ Atropin ve $0,03 \mathrm{mg} / \mathrm{kg}$ Neostigmin ile nöromuskuler bloker geri döndürülmesi uygulandı. Spontan solunumu ve hava yolu refleksleri yeterli düzeye gelince ekstübe edildi. Ameliyatın cerrahi başlangıcından, son sutur atılana kadar geçen süre ameliyat süresi, anestezi indüksiyonu başlangıcından hastanın uyanmasına kadar geçen süre anestezi süresi olarak, perioperatif toplam fentanil tüketimi kaydedildi.

Olgular postoperatif $0,2,4,6,8,10,12,16,24$ saatlerde bulantı, kusma açısından değerlendirildi. Bulantı kusma Verbal Destriktif Skala (VDS) (Bulantı yok=0; Hafif=1; Orta=2; Şiddetli=3) ile değerlendirildi. VDS $>2$ ise metokloropramid i.v. yapıldı. VDS, toplam antiemetik tüketimleri kaydedildi. Kusma varlığı, 24 saat süreyle takip edilen olgular yan etkileri (Baş ağrısı, sedasyon, yüzde kızarıklık) açısından kaydedildi.

Postoperatif takibi nöroşirurji yoğun bakım ünitesindeki hemşireler uyguladı. Nöroşirurji yoğun bakım ünitesinde takip eden hemşireler olguların gruplamasından haberdar edilmediler.

\section{İstatiksel Analiz}

Verilerin analizi SPSS for Windows 11.5 paket programında yapıldı. Verilerin değerlendirilmesinde tanımlayıcı istatistiksel metotların (ortalama,standart sapma) yanı sıra çoklu grupların tekrarlayan ölçümlerinde Friedman testi, gruplar arası karşılaştırmalarda Kruskal Wallis testi alt grup karşılaştırmalarında Dunn's çoklu karşılaştırma testi, nitel verilerin karşılaştırmalarında ki-kare testi, nitel verilerin tekrarlayan ölçümlerinde Mc.Nemar's testi kullanılmıştır. Sonuçlar, anlamlılık $p<0,05$ düzeyinde değerlendirilmiştir.

\section{BULGULAR}

Grup 1, Grup 2 ve Grup 3 ün yaş ortalamaları, cinsiyet, Anestezi Süresi ortalamaları, Operasyon Süresi ortalamaları, Analjezik Miktarı (Perioperatif fentanil tüketimi) ortalamaları arasında istatistiksel olarak anlamlı farklılık gözlenmemiştir (Tablo 1).

Grup 1, Grup 2 ve Grup 3 ün 0.Saat, 2.Saat, 4.Saat, 6.Saat, 8.Saat, 10.Saat bulantı şiddeti dağılımları arasında istatistiksel olarak anlamlı farklılık gözlenmiştir $(p=0,0001)$. Grup 1 de bulantı varlığı Grup 2 ve Grup 3'den istatistiksel olarak anlamlı derecede yüksek bulunmuştur. Grup 1, Grup 2 ve Grup 3'ün 12.Saat, 16.Saat, 20.Saat, 24.Saat bulantı şiddeti dağılımları arasında istatistiksel olarak anlamlı farklılık gözlenmemiştir. Grup 1 (Plasebo) in 0.Saat, 2. Saat, 4.Saat, 6.Saat Bulantı şiddeti dağılımları 8.Saat, 10.Saat, 12.Saat, 16.Saat, 20.Saat, 24.Saat bulantı şiddeti dağılımlarından istatistiksel olarak anlamlı derecede yüksek bulunmuş ( $p=0,0001, p=0,031$ ), diğer zamanlar arasında istatistiksel olarak anlamlı farklılık gözlenmemiştir. Grup 2 (Ondansetron) in 0.Saat, 2.Saat, 4.Saat Bulantı şiddeti $(p=0,0001$, $\mathrm{p}=0,011$ ), dağılımları 6.Saat, 8.Saat, 10.Saat, 12 . Saat, 16.Saat, 20.Saat, 24.Saat bulantı şiddeti dağıIımlarından istatistiksel olarak anlamlı derecede yüksek bulunmuş $(p=0,009, p=0,002)$, diğer zamanlar arasında istatistiksel olarak anlamlı farklılık gözlenmemiştir. Grup 3 (Granisetron) in 0.Saat Bulantı şiddeti dağılımları 4.Saat, 6.Saat, 8.Saat, 10.Saat, 12. Saat, 16.Saat, 20.Saat, 24.Saat bulantı şiddeti dağıIımlarından istatistiksel olarak anlamlı derecede yüksek bulunmuş $(p=0,017, p=0,018)$, diğer zamanlar arasında istatistiksel olarak anlamlı farklılık gözlenmemiştir (Tablo 2, Şekil 1).

Grup 1, Grup 2 ve Grup 3'ün 0.Saat, 2.Saat, 4.Saat, 6.Saat, 8.Saat, 10.Saat kusma varlığı dağılım-

Tablo 1: Demografik Veriler

\begin{tabular}{|c|c|c|c|c|}
\hline & Grup 1 & Grup 2 & Grup 3 & \\
\hline Yaş & $52,47 \pm 11,01$ & $51,17 \pm 8,96$ & $46,33 \pm 13,57$ & $K W: 2,81 p=0,245$ \\
\hline Cinsiyet & $13 \quad 43,3 \%$ & $11 \quad 36,7 \%$ & $17 \quad 56,7 \%$ & $\chi^{2}: 2,5$ \\
\hline Kadın & $17 \quad 56,7 \%$ & $19 \quad 63,3 \%$ & $13 \quad 43,3 \%$ & $p=0,285$ \\
\hline Anestezi Süresi & $207,5 \pm 24,45$ & $216,67 \pm 33,33$ & $217,83 \pm 36,38$ & $K W: 2,2 p=0,332$ \\
\hline Operasyon Süresi & $181,17 \pm 23,11$ & $192,83 \pm 29,62$ & $194,83 \pm 35,32$ & $K W: 4,36 p=0,113$ \\
\hline Analjezik Miktarı & $298,83 \pm 52,31$ & $316,67 \pm 62,74$ & $320 \pm 57,76$ & $K W: 3,29 \quad p=0,167$ \\
\hline
\end{tabular}


Tablo 2: Gruplar Arası Bulantı Şiddeti

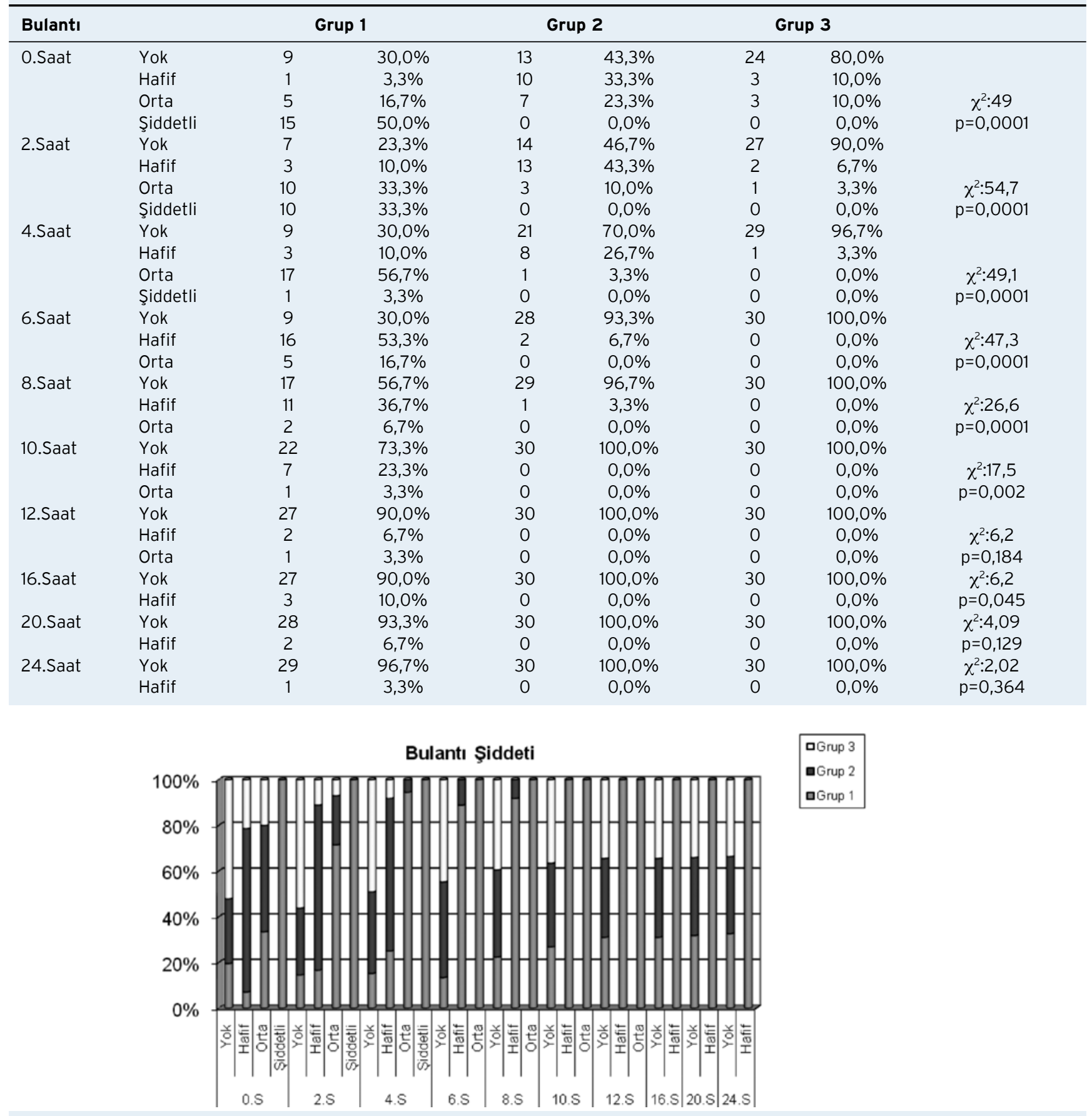

Şekil 1: Gruplar Arası Bulantı Şiddeti

ları arasında istatistiksel olarak anlamlı farklılık gözlenmiştir ( $p=0,0001)$. Grup 1'de kusma varlığı Grup 2 ve Grup 3'den istatistiksel olarak anlamlı derecede yüksek bulunmuştur. Grup 1, Grup 2 ve Grup 3'ün 12.Saat, 16.Saat 20.Saat, 24.Saat kusma varlığı dağı- lımları arasında istatistiksel olarak anlamlı farklılık gözlenmemiştir. Grup 1 (Plasebo)in 0.Saat, 2.Saat, 4.Saat Kusma varlığı dağılımları 6.Saat, 10.Saat, 12. Saat, 16.Saat, 20.Saat, 24.Saat Kusma varlığı dağılımlarından istatistiksel olarak anlamlı derecede yüksek 
Tablo 3: Gruplar Arası Kusma Varlığı

\begin{tabular}{|c|c|c|c|c|c|c|c|c|}
\hline \multicolumn{2}{|l|}{ Kusma } & \multicolumn{2}{|c|}{ Grup 1} & \multicolumn{2}{|c|}{ Grup 2} & \multicolumn{2}{|c|}{ Grup 3} & \multirow[b]{2}{*}{$\chi^{2}: 43,9$} \\
\hline O.Saat & Yok & 9 & $30,0 \%$ & 27 & $90,0 \%$ & 30 & $100,0 \%$ & \\
\hline & Var & 21 & $70,0 \%$ & 3 & $10,0 \%$ & 0 & $0,0 \%$ & $p=0,0001$ \\
\hline \multirow[t]{2}{*}{ 2.Saat } & Yok & 8 & $26,7 \%$ & 26 & $86,7 \%$ & 28 & $93,3 \%$ & $\chi^{2}: 37,7$ \\
\hline & Var & 22 & $73,3 \%$ & 4 & $13,3 \%$ & 2 & $6,7 \%$ & $p=0,0001$ \\
\hline \multirow[t]{2}{*}{ 4.Saat } & Yok & 21 & $70,0 \%$ & 27 & $90,0 \%$ & 30 & $100,0 \%$ & $\chi^{2}: 12,1$ \\
\hline & Var & 9 & $30,0 \%$ & 3 & $10,0 \%$ & 0 & $0,0 \%$ & $p=0,002$ \\
\hline \multirow[t]{2}{*}{ 6.Saat } & Yok & 25 & $83,3 \%$ & 30 & $100,0 \%$ & 30 & $100,0 \%$ & $\chi^{2}: 10,5$ \\
\hline & Var & 5 & $16,7 \%$ & 0 & $0,0 \%$ & 0 & $0,0 \%$ & $p=0,005$ \\
\hline \multirow[t]{2}{*}{ 8.Saat } & Yok & 27 & $90,0 \%$ & 30 & $100,0 \%$ & 30 & $100,0 \%$ & $\chi^{2}: 6,2$ \\
\hline & Var & 3 & $10,0 \%$ & 0 & $0,0 \%$ & 0 & $0,0 \%$ & $p=0,045$ \\
\hline \multirow[t]{2}{*}{ 10.Saat } & Yok & 26 & $86,7 \%$ & 30 & $100,0 \%$ & 30 & $100,0 \%$ & $\chi^{2}: 8,37$ \\
\hline & Var & 4 & $13,3 \%$ & 0 & $0,0 \%$ & 0 & $0,0 \%$ & $\mathrm{p}=0,015$ \\
\hline \multirow[t]{2}{*}{ 12.Saat } & Yok & 29 & $96,7 \%$ & 30 & $100,0 \%$ & 30 & $100,0 \%$ & $\chi^{2}: 2,02$ \\
\hline & Var & 1 & $3,3 \%$ & 0 & $0,0 \%$ & 0 & $0,0 \%$ & $p=0,364$ \\
\hline \multirow[t]{2}{*}{ 16.Saat } & Yok & 28 & $93,3 \%$ & 30 & $100,0 \%$ & 30 & $100,0 \%$ & $\chi^{2}: 4,09$ \\
\hline & Var & 2 & $6,7 \%$ & 0 & $0,0 \%$ & 0 & $0,0 \%$ & $p=0,129$ \\
\hline \multirow[t]{2}{*}{ 20.Saat } & Yok & 28 & $93,3 \%$ & 30 & $100,0 \%$ & 30 & $100,0 \%$ & $x^{2}: 4,09$ \\
\hline & Var & 2 & $6,7 \%$ & 0 & $0,0 \%$ & 0 & $0,0 \%$ & $p=0,129$ \\
\hline \multirow[t]{2}{*}{ 24.Saat } & Yok & 30 & $100,0 \%$ & 29 & $96,7 \%$ & 30 & $100,0 \%$ & $\chi^{2}: 2,02$ \\
\hline & Var & 0 & $0,0 \%$ & 1 & $3,3 \%$ & 0 & $0,0 \%$ & $p=0,364$ \\
\hline
\end{tabular}

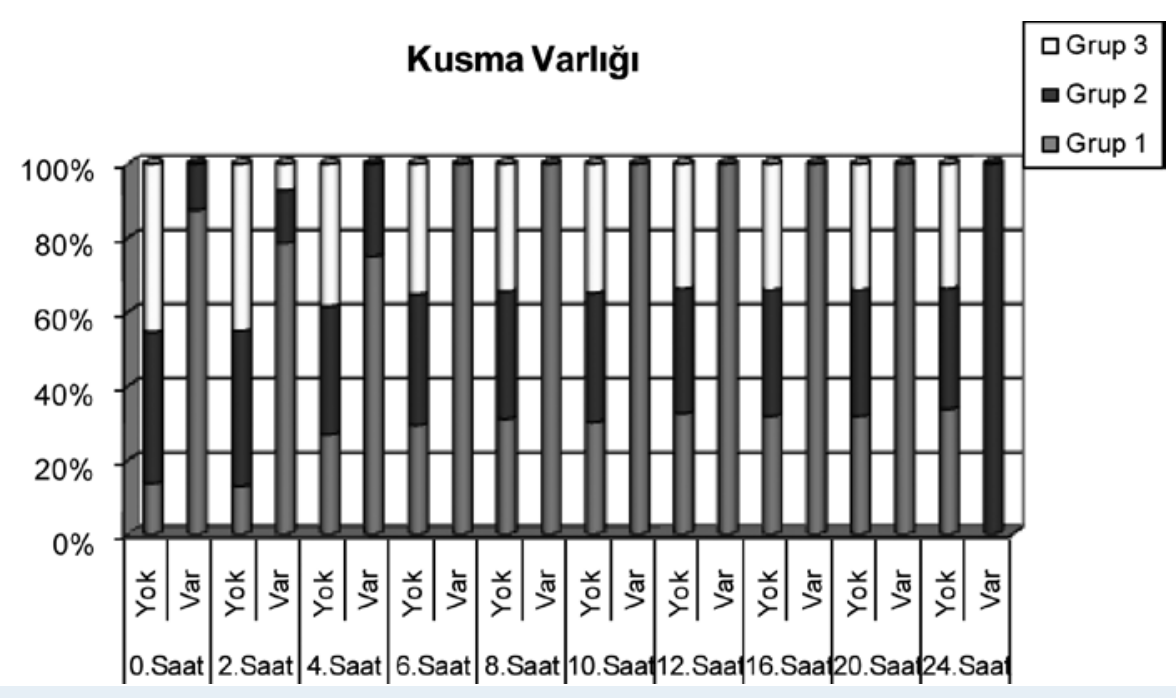

Şekil 2: Gruplar Arası Bulantı Şiddeti

bulunmuş $(p=0,0001, p=0,008, p=0,039)$, diğer zamanlar arasında istatistiksel olarak anlamlı farklılık gözlenmemiştir. Grup 2 (Ondansetron) in 0.Saat, 2. Saat Kusma varlığı dağılımları 24.Saat Kusma varlığı dağılımlarından istatistiksel olarak anlamlı derecede yüksek bulunmuş $(p=0,033)$, 2.Saat Kusma varlığı dağılımları 24.Saat Kusma varlığı dağılımlarından istatistiksel olarak anlamlı derecede yüksek bulunmuş ( $p=0,022)$, diğer zamanlar arasında istatistiksel olarak anlamlı farklılık gözlenmemiştir. Grup 3 (Gra- nisetron) in 0.Saat, 2.saat, 4.Saat, 6.Saat, 8.Saat, 10.Saat, 12.Saat, 16.Saat, 20.Saat, 24.Saat Kusma varlığı dağılımların arasında istatistiksel olarak anlamlı farklılık gözlenmemiştir (Tablo 3, Şekil 2).

Grup 1, Grup 2 ve Grup 3'ün antiemetik ihtiyacı varlığı dağılımları arasında istatistiksel olarak anlamlı farklılık gözlenmiştir ( $p=0,02)$. Grup $1^{\prime}$ de antiemetik ihtiyacı varlığı Grup 2 ve Grup 3'den istatistiksel olarak anlamlı derecede yüksek bulunmuştur (Tablo 4). Grupların hiçbirinde yan etki ile karşılaşılmamıştır. 
Tablo 4: Antiemetik kullanımı

\begin{tabular}{|c|c|c|c|c|c|c|c|}
\hline & \multicolumn{2}{|c|}{ Grup 1} & \multicolumn{2}{|c|}{ Grup 2} & \multicolumn{2}{|c|}{ Grup 3} & \\
\hline \multicolumn{8}{|l|}{ Antiemetik intiyacı } \\
\hline Yok & 21 & $70,0 \%$ & 27 & $90,0 \%$ & 28 & $93,3 \%$ & $\chi^{2}: 7,27$ \\
\hline Var & 9 & $30,0 \%$ & 3 & $10,0 \%$ & 2 & $6,7 \%$ & $p=0,02$ \\
\hline
\end{tabular}

\section{TARTIŞMA}

POBK, anestezi sonrası en sık görülen yan etkidir. Operasyon sonrası hastaların dörtte biri POBK yaşarlar. POBK, hastanede kalış süresini uzatır ve buna bağlı olarak ta maliyette artışa sebep olur (6). POBK, genel cerrahi operasyonları geçiren hasta gruplarında nadiren majör komplikasyonlara yol açsada, postkraniyotomi hastalarında KiBAS'a yol açarak intrakraniyal kanama olasılığını arttırır. Kraniyotomi sonrası POBK insidansının \%50 -73 arasında olduğu bildirilmiştir (7). POBK postoperatif tansiyon regülasyonunu güçleştirmekte, ilaveten intrathorasik, intraabdominal ve intraoküler basıncı arttırmaktadır. Sıvıelektrolit kayıpları, aspirasyon ve buna bağlı solunum sıkıntısı da görülebilecek komplikasyonlar arasındadır (7).

POBK gelişmesine engel olmak amacıyla, POBK açısından riskli olduğu düşünülen cerrahi geçirecek hasta gruplarında rutin bir multimodel antiemetik profilaksi uygulanması gündeme gelmiştir (8).

Deksametazon antiemetik etkinliği olan bir kortikosteroid ajandır. POBK insidansını geç ancak uzun etkili olarak azaltır (9). Deksametazonun tek doz olarak anestezi indüksiyonu öncesi veya sonrası uygulandığında 5-HT3 reseptörlerine antagonist etkinliği olduğu bulunmuştur (9). Erhan ve arkadaşları POBK'da 8 mg deksametazonu, 5HT3 antogonistleri ile benzer etkinlikte bulmuşlardır (10). Bizim çalışmamızda da olgulara operasyondan 24 saat önce deksametazon verildi ve postoperatif dönemde de uygulamaya devam edildi.

Kraniyotomi geçiren olgularda, dura kapatılırken i.v. 4 mg uygulanan ondansetronun etkinliğinin plasebo ile karşılaştırıldığı farklı çalışmalarda, POBK görülme sıklığının ve antiemetik ihtiyacının azaldığı tespit edilmiştir $(11,12)$. Hartsell ve arkadaşları, akustik nörinom ameliyatı olan 60 olguda perioperatif dönemde i.v. 4 mg ondansetron ile plasebo uygula- mışlar, ardından postoperatif 72 saatlik dönemde de oral $8 \mathrm{mg}$ ondansetron ve plasebo uygulamasına devam etmişlerdir. Ondansetronun plaseboya oranla POBK sıklığını, ek doz antiemetik kullanımını özellikle erken dönemde azalttı̆̆ını tespit etmişlerdir (13). Frost ve arkadaşları da, bir metaanalizde kraniyotomi geçiren erişkin ve çocuklarda ondansetron kullanımının POBK'yı önlediğini söylemişlerdir. Erişkin için 4 mg ondansetron kullanımının yeterli olduğunu vurgulamışlardır (14). Diğer taraftan yapılan bir çalışmada ondansetronun dura kapatılırken verilmesinin post operatif bulantı kusmayı önlemede kısmen etkili olduğu gösterilmiştir (15).

Pugh ve arkadaşlarının çalışmasında ondansetron ve metoklopropamid karşılaştırılmış, ondansetron grubunda POBK daha yüksek bulunmuştur (2). Krobbuaban ve arkadaşları ise jinokolojik cerrahi sonrası, ondansetronun metoklopropamide göre POBK'u azalttığını söylemişlerdir (16). Öksüz ve arkadaşları da, laparoskopik kolesistektomi sonrası metoklopramid, granisetron ve ondansetronu POBK sıklığı açısından karşılaştırmışlardır. Postoperatif ilk 3 saatte tüm ajanları benzer bulmuşlar, 4-24. Saatlaer arasında ise metoklopramidi etkisiz, granisetronu ise POBK'yı azaltmada en etkin antiemetik olarak değerlendirmişlerdir (17).

Wang ve arkadaşlarının, supratentoriyal kraniyotomilerde granisetronu plasebo ile karşılaştırdıkları

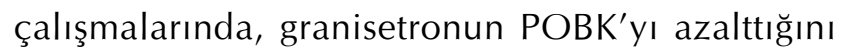
göstermişlerdir (18).

Quan ve arkadaşları, POBK açısından yüksek riskli kadın cinsiyet, sigara içmeme, opioid kullanma gibi risk faktörlerini içeren olguları dahil ettikleri çalışmalarında, 4 mg ondansetron, 3 mg granisetronun i.v. kullanımını karşılaştırmışlar ve $\mathrm{POBK}^{\prime} \mathrm{yı}$ azaltmada granisetronu daha etkin bulmuşlardır (19). 85 çalışma ve 15269 olgununyer aldığı bir metaanalizde ondansetron, granisetron, tropisetron ve dolasetronun POBK üzerindeki etkinliği araştırılmış ve 
tüm ajanların etkin olduğu, anacak granisetronun diğer 5HT3 antogonistlerinden daha güçlü etki gösterdiği vurgulanmıştır (5).

Kovac ve arkadaşlarının yayınladığı bir metaanalizde, 5 HT3 antogonistlerinin etkilerini deksametazon kullanımının potansiyelize ettiği ortaya konmuştur (20). Wig J ve arkadaşlarının çalışmasında preoperatif steroid alan subratentoriyol kitle nedeniyle kraniyotomi yapılan olgularda POBK'da profilaktik olarak verilen ondansetronun etkinliği araştırılmış ve POBK ondansetron grubunda daha düşük bulunmuştur (21).

Neudffeld ve Newburn-Cook'un 7 çalışmayı ve 448 olguyu dahil ettikleri metaanalizde, ondansetron, granisetron ve tropisetron gibi 5-HT3 reseptör antagonisterinin, nöroşirürjikal hastalarda, bulantıdan ziyade kusmayı engellemede efektif olduğunu göstermişlerdir (22).

Jain ve arkadaşlarının çalışmasında da dura kapatılırken i.v. ondansetron ve granisetronun profilaktik uygulanması plaseboyla karşılaştırılmış, bulantı insidansında düşüş görülmemiş, ancak ondansetron veya granisetron alan olgularda kusma sıklığı ve ek doz antiemetik gereksinimi anlamlı ölçüde düşmüştür (23).

\section{KAYNAKLAR}

1. Watcha MF, White PF. Postoperative nausea and vomiting. Its etiology, treatment, and prevention. Anesthesiology 1992;77(1):162-84.

2. Pugh SC, Jones NC, Barsoum LZ. A Comparison of Prophylactic Ondansetron and Metoclopramide in Patients Undergoing Major Neurosurgical procedures. Anaesthesia 1996;51(12):1164-66.

3. Fabling JM, Gan TJ, El-Moalem HE, et al. A Randomized, Double Blinded comparison of Ondansetron, Droperidol and Placebo for Prevention of Postoperative Nausea and Vomiting After Supratentorial Craniotomy. Anesth Analg 2000;91(2):358-61.

4. Habib AS, Keifer JC, Borel CO, White WD, Gan TJ. A comparison of the combination of aprepitant and dexamethasone versus the combination of ondansetron and dexamethasone for the prevention of postoperative nausea and vomiting in patients undergoing craniotomy. Anesth Analg 2011;112(4):813-8.

5. Tang DH, Malone DC. A network meta-analysis on the efficacy of serotonin type 3 receptor antagonists used in adults during the first 24 hours for postoperative nausea and vomiting prophylaxis. Clin Ther 2012;34(2):282-94.

6. Gold BS, Kitz DS, Lecky JH \& Neuhaus JM. Unanticipated Admission to the Hospital Following Ambulatory Surgery. JAMA 1989;262(21):3008-10.
Çalışmamızda, ondansetron ve granisetron grubunun kraniyotomiden sonraki 24 saat içinde bulantı insidansı, kontrol grubuna kıyasla istatistiksel olarak anlamlı derecede daha düşüktü. Kontrol grubunda ilk 6 saatteki, ondansetron grubunda ilk 4 saatteki, granisetron grubunda 1.saatteki bulantı varlığı diğer zamanlara göre istatiksel olarak anlamlı derecede yüksek bulunmuştur. Bununla beraber, ondansetron ve granisetron gruplarında kusma insidansları da ilk 10 saatte kontrol grubuna göre istatistiksel olarak anlamlı derecede düşüktü. Kontrol grubunda ilk 4 saatteki, ondansetron grubunda ilk 2 saatteki kusma varlığı diğer saatlere göre istatistiksel olarak anlamlı derecede yüksekti. Granisetron grubunda hiç kusma görülmedi. Granisetron ve ondansetron gruplarında ek doz antiemetik ihtiyacı kontrol gubuna göre istatistiksel olarak anlamlı derecede düşüktü.

Sonuç olarak supratentorial kitle nedeniyle opere olan olgularda deksametazonun tek başına antiemetik etkinliğinin yeterli olmadığı, ondansetron ve granisetron ile kombine kullanıldığında POBK'un önlenmesinde etkili olduğunu tespit ettik. Granisetron alan hasta grubunda daha az bulantı-kusma görülmesine rağmen ondansetron ve granisetron POBK açısından benzer etkinlik göstermiştir.

7. Eberhart $L H$, Morin AM, Kranke P, Missaghi NB, Durieux ME, Himmelseher S. Prevention and control of postoperative nausea and vomiting in post-craniotomy patients.Best Pract Res Clin Anaesthesiol 2007;21(4):575-93.

8. Gan TJ, Meyer T, Apfel CC et al. Consensus Guidelines for Managing Postoperative Nausea and Vomiting. Anesthesia and Analgesia 2003;97(1):62-71.

9. Henzi I,Walder B,Tramer MR Dexametazon for the Prevention of Postoperative Nausea and Vomiting:A Quantative systematic review Anest. Analg 2000;90(1):186-94.

10. Erhan $Y$, Erhan E, Aydede H, Yumus O, Yentur A. Ondansetron, granisetron, and dexamethasone compared for the prevention of postoperative nausea and vomiting in patients undergoing laparoscopic cholecystectomy: A randomized placebo-controlled study. Surg Endosc 2008;22(6):1487-92.

11. Sinha PK, Tripathi $M$, Ambesh SP. Efficacy of Ondansetron in Prophylaxis of Postoperative Nausea and Vomiting in Patients following Infratentorial Surgery: A Placebo Controlled Prospective Double Blind Study. J Neurosurg Anesthesiol 1999;11(1):6-10.

12. Kathirvel S, Dash HH, Bhatia A, et al. Effect of Prophylactic Ondansetron on Postoperative Nausea and Vomiting After Elective Craniotomy. J Neurosurg Anesthesiol 2001;13(3):20712. 
13. Hartsell T, Long D \& Kirsch JR. The Efficacy of Postoperative Ondansetron (Zofran) Orally DisintegratingT for Preventing Nausea and Vomiting After Acoustic Neuroma Surgery.Anesth Analg 2005;101(5):1492-6.

14. Frost F, Dailler F, Duflo F. Ondansetron: a meta-analysis on its efficacy to prevent postoperative nausea and vomiting after craniotomy in adults and children .Ann Fr Anesth Reanim 2010;29(1):19-24.

15. Fabling JM, Gan TJ, El-Moalem HF, et al. A Randomized, Double Blind Comparison of Ondansetron Versus Placebo for Prevention of Nausea and Vomiting after Infratentorial Craniotomy. J Neurosurg Anesthesiol 2002;14(2):102-7.

16. Krobbuaban B, Pitakpol S, Diregpoke S. Ondansetron vs. metoclopramide for the prevention of nausea and vomiting after gynecologic surgery. J Med Assoc Thai 2008;91(5):669-74.

17. Oksuz H, Zencirci B, Ezberci M. Comparison of the effectiveness of metoclopramide, ondansetron, and granisetron on the prevention of nausea and vomiting after laparoscopic cholecystectomy. J Laparoendosc Adv Surg Tech A 2007;17(6):803-8.

18. Wang YJ, Cheng ZG, Guo QL. Clinical observation of granisetron in preventing postoperative nausea and vomiting following supratentorial craniotomy Hunan Yi Ke Da Xue Xue Bao 2002;27(6):545-6.
19. Quan X, Zhu B, Ye TH. Preventive efficacy of ondansetron and granisetron for postoperative nausea and vomiting in high risk patients. Zhongguo Yi Xue Ke Xue Yuan Xue Bao 2011;33(4):445-8.

20. Kovac AL. Meta-analysis of the use of rescue antiemetics following PONV prophylactic failure with 5-HT3 antagonist/ dexamethasone versus single-agent therapies. Ann Pharmacother 2006;40(5):873-87.

21. Wig J, Chandrashekharappa KN, Yaddanapudi LN, Nakra $D$, Mukherjee KK. Effect of prophylactic ondansetron on postoperative nausea and vomiting in patients on preoperative steroids undergoing craniotomy for supratentorial tumors. J Neurosurg Anesthesiol 2007;19(4):239-42.

22. Neufeld SM, Newburn-Cook CV. The efficacy of 5-HT3 receptor antagonists for the prevention of postoperative nausea and vomiting after craniotomy: a meta-analysis. I Neurosurg Anesthesiol 2007;19(1):10-7.

23. Jain V, Mitra JK, Rath GP, Prabhakar H, Bithal PK, Dash HH. A randomized, double-blinded comparison of ondansetron, granisetron, and placebo for prevention of postoperative nausea and vomiting after supratentorial craniotomy. I Neurosurg Anesthesiol 2009;21(3):226-30. 